\title{
Analisis Aplikasi Mobile Transportasi Online Menggunakan User Experience Questionnaire pada Era Milenial dan Z
}

\author{
Leon Andretti Abdillah*
}

Information Systems Department, Universitas Bina Darma

Naskah Diterima : 26 Oktober 2019; Diterima Publikasi : 11 November 2019

DOI : 10.21456/vol9iss2pp204-211

\begin{abstract}
Online transportation becomes so popular in the ride-sharing industry. Young millennial and $\mathrm{z}$ generation users utilize their smartphone not only for communications but also for ordering online transportation services like Gojek. This study examines the experience of millennial and $\mathrm{z}$ generation students in using the well-known Gojek online transportation mobile service. A number of 154 millennial computer science students as respondents are involved in this study. Their experience in using online mobile transportation services via smartphone was collected through an online questionnaire made using google forms and distributed via Facebook. The tool used in this study is Online User Experience Questionnaire (UEQ). The results showed that all UEQ categories scored in positive areas. The highest score is in the "Perspicuity" category, while the lowest score is in the "Novelty" category. The benchmark value of the Gojek application indicates that the Gojek application has a rating scale that is on the scale of "above average" and "good". Suggestions that can be taken from the results of research that the Gojek application in general has been very good in providing experience for its users, things that need to be improved is in terms of the renewal of the application.
\end{abstract}

Keywords: User Experience, Millennial And Z Generation Students, Gojek, Online Transportation

\begin{abstract}
Abstrak
Transportasi online menjadi sangat populer di industri berbagi perjalanan. Pengguna generasi muda milenium dan generasi z memanfaatkan smartphone mereka tidak hanya untuk komunikasi tetapi juga untuk memesan layanan transportasi online seperti Gojek. Penelitian ini menelaah pengalaman mahasiswa generasi milenial dan z dalam menggunakan layanan mobile transportasi online Gojek yang terkenal. Sejumlah 154 mahasiswa ilmu komputer milenium sebagai responden terlibat dalam penelitian ini. Pengalaman mereka dalam menggunakan layanan transportasi seluler online melalui smartphone dikumpulkan melalui kuesioner online yang dibuat menggunakan formulir google dan didistribusikan melalui Facebook. Alat yang digunakan pada penelitian ini adalah User Experience Questionnaire (UEQ). Hasil penelitian menunjukkan bahwa semua kategori UEQ memperoleh skor pada area positif. Nilai tertinggi diraih oleh kategori "Perspicuity", sedangkan skor terendah diraih oleh kategori "Novelty". Nilai benchmark aplikasi Gojek menunjukkan bahwa aplikasi Gojek memiliki skala penilaian yang berada pada skala "above average" dan "good". Saran yang dapat diambil dari hasil penelitian bahwa aplikasi Gojek secara umum sudah sangat baik dalam memberikan pengalaman bagi para penggunanya, hal yang perlu ditingkatkan adalah dari sisi keterbaruan aplikasinya
\end{abstract}

Kata kunci: Pengalaman Pengguna, Mahasiswa Milenial Dan Generasi Z, Gojek, Transportasi Online

\section{Pendahuluan}

Globalisasi dan pertumbuhan populasi telah mendorong pengembangan mobilitas alternatif bagi masyarakat dengan melibatkan kemajuan teknologi informasi (TI). Perkembangan teknologi informasi telah bergeser ke era mobile dan ubiquitous computing. Pada saat ini komputer tidak lagi dianggap sebagai mesin berbasis elektronik yang dapat digunakan untuk mengolah data menjadi informasi saja. Salah satu perangkat yang paling sering digabungkan dengan komputer adalah ponsel

\footnotetext{
*) Penulis korespondensi: leon.abdillah @ yahoo.com
}

yang dikenal sebagai "smartphone". Dengan teknologi terbaru, smartphone telah menjadi gadget yang paling sering digunakan oleh banyak pihak terutama kaum muda atau generasi milenial dan $\mathrm{z}$. Generasi baru ponsel adalah contoh yang baik tentang keberadaan "ubiquity of computing technology" dan fokus pada peningkatan pengalaman pengguna (Swallow et al., 2005). User experience questionnaire (UEQ) memungkinkan penilaian cepat pengalaman pengguna untuk produk interaktif apapun (Rauschenberger et al., 2013). Dalam penelitian ini akan menganalisis bagaimana 
pengalaman pengguna generasi milenial dan $\mathrm{z}$ dalam menggunakan aplikasi mobile transrpotasi online dengan menggunakan UEQ. Objek penelitian adalah mahasiswa muda ilmu komputer generasi milenium dan $\mathrm{z}$ yang aktif dalam menggunakan aplikasi transportasi online.

Pengguna internet di Indonesia pada tahun 2018 setara dengan 150 juta orang atau menempati ranking ketiga di Asia Pasific (Statista, 2019a) setelah China dan India (Tabel 1). Data pada tabel 1 juga menunjukkan bahwa Indonesia menempati rangking pertama untuk wilayah ASEAN.

Tabel 1. Pengguna internet di Asia Pasific.

\begin{tabular}{clc}
\hline \multirow{2}{*}{ Ranking } & \multicolumn{1}{c}{ Negara } & $\begin{array}{c}\text { Jumlah Pengguna Internet } \\
\text { (Juta) }\end{array}$ \\
\hline 1 & China & 802,00 \\
2 & India & 560,00 \\
3 & Indonesia & 150,00 \\
4 & Japan & 118,90 \\
5 & Bangladesh & 91,82 \\
6 & Philippines & 76,00 \\
7 & Vietnam & 64,00 \\
8 & Thailand & 57,00 \\
9 & South Korea & 48,74 \\
10 & Pakistan & 44,61 \\
\hline
\end{tabular}

Di antara para pengguna itu, 76,64 juta (Statista, 2019b) diprediksi sebagai pengguna smartphone. Pada bulan Januari 2019 (Kemp, 2019), total koneksi global ada sekitar 7,676 miliar, dimana koneksi menggunakan "mobile device" sekitar 5,112 miliar atau setara dengan 67\% (Tabel 2).

Tabel 2. "Digital Around The World" pada tahun 2019.

\begin{tabular}{clcc}
\hline No & \multicolumn{1}{c}{ Keterangan } & $\begin{array}{c}\text { Jumlah } \\
\text { Pengguna } \\
\text { Internet (Miliar) }\end{array}$ & Persentase \\
\hline 1 & Total Population & 7,676 & $56 \%$ \\
2 & Unique Mobile Users & 5,112 & $67 \%$ \\
3 & Internet Users & 4,388 & $57 \%$ \\
4 & $\begin{array}{l}\text { Active Social Media } \\
\text { Users }\end{array}$ & 3,848 & $45 \%$ \\
5 & $\begin{array}{l}\text { Mobile Social Media } \\
\text { Users }\end{array}$ & 3,256 & $42 \%$ \\
\hline
\end{tabular}

Jumlah pengguna smartphone di Indonesia meningkat dengan pesat seiring dengan pertumbuhan income, gross domestic product (GDP), purchasing power parity (PPP), serta sebuah hasil penelitian menunjukkan bahwa, pada tingkat yang berbeda, orang yang lebih muda dan lebih berpendidikan memanfaatkan internet seluler, terutama melalui smartphone (Puspitasari \& Ishii, 2016). Pada tahun 2017, GDP Indonesia telah melampaui USD 1 triliun dan berada pada ranking ke-16 di dunia dan nomor 1 (satu) di Asia Tenggara. Bahkan untuk PPP, Indonesia berada di peringkat ke-7. Di lain pihak, harga smartphone cenderung semakin terjangkau. Pertumbuhan ekonomi yang stabil dan harga smartphone yang kian terjangkau membuat pertumbuhan penggunaan smartphone semakin meningkat di Indonesia.
Diantara para pengguna smartphone tersebut, para pengguna milenial adalah yang dominan. Hampir setiap negara, generasi milenium jauh lebih mungkin menjadi pengguna internet dan smartphone dibandingkan dengan mereka yang berusia 35 dan lebih tua (Poushter, 2016).

Gojek merupakan salah satu aplikasi transportasi online yang paling populer di Indonesia. Aplikasi ini merupakan berbasis teknologi cloud (Abdillah et al., 2017) yang menawarkan beragam pilihan layanan untuk para penggunanya. Gojek sebagai perusahaan "ride-hailing" adalah "top number one Unicorns" di Indonesia diikuti oleh market place "Tokopedia", travel site "Traveloka", market place "Bukalapak", dan yang baru muncul yaitu financial technology (FinTech) "OVO". Unicorn adalah sebutan yang dipopulerkan oleh Aileen Lee, pendiri perusahaan modal ventura Cowboy Ventures, untuk perusahaan rintisan (start-up) yang memiliki nilai lebih dari US\$1 miliar. Pada 2017, Gojek dinobatkan sebagai perusahaan Fintech paling proaktif yang mendukung Gerakan Non-Tunai Nasional (Rahardjo \& Sugiarto, 2019). Gojek merupakan perusahaan "Unicorn" Indonesia pertama yang diraih pada bulan Agustus 2016, dan salah satu perusahaan layanan internet terbesar dan dipimpin oleh "transformational leadership", Nadiem Makarim (Junita, 2019). Pada tahun 2019 Gojek berhasil meraih predikat "Decacorn" atau perusahaan rintisan dengan nilai mencapai lebih dari US\$10 miliar.

Tujuan penelitian ini menganalisis aplikasi mobile tansportasi online menggunakan user experience questionnaire pada era milenial dan $\mathrm{Z}$. Data diambil dari Mahasiswa Ilmu Komputer Generasi Milenial dan $\mathrm{Z}$ dalam menggunakan layanan Gojek melalui aplikasi berbasis smartphone yang terkenal.

\section{Kerangka Teori}

Berikut sejumlah teori yang terpakai pada penelitian ini dan dapat menggambarkan pengalaman (experience) mahasiswa ilmu komputer (generasi milenial dan z) ketika menggunakan jasa transportasi online.

\subsection{Aplikasi Mobile Transportasi Online}

Carpooling, demikian juga "ride-sharing", barubaru ini mulai menjadi menarik secara global (Dimitrijević et al., 2013). Istilah transportasi online mulai marak di Indonesia sejak kemunculan Gojek. Dengan business model berbasis IT, transportasi online telah menjelma menjadi idola mobilitas bagi sebagian besar penduduk Indonesia terutama kalangan generasi milenial dan $\mathrm{z}$.

Sebagai salah satu varian dari e-Commerce (Silalahi et al., 2017), kelebihan utama dari transportasi online adalah baik driver dan customer sama-sama mengetahui dimana posisi masing-masing 
serta kisaran biayanya. Di Indonesia sendiri ada keunikan dengan adanya pergeseran dari ojek konvensional ke ojek online. Pemain utama di sektor online ojek adalah Go-Ride dari Gojek dan GrabBike dari Grab.

Lebih lanjut, IT yang kolaborasi dengan smartphone, tren e-Commerce juga mengalami penyesuaian menjadi mobile commerce ( $\mathrm{m}$ Commerce). Para generasi milenial dan $\mathrm{z}$ dapat dengan mudah melakukan order transportasi online hanya dengan menggunakan smartphone mereka. Perkembangan m-Commerce juga mengalami peningkatan pesat di Indonesia (Septiani et al., 2017).

Pada skema aplikasi mobile transportasi online, pelanggan akan melakukan order melalui aplikasi mobile yang dilengkapi dengan teknologi LocationBased Service (LBS). LBS adalah salah satu layanan (service) yang aktif bertindak untuk mengubah posisi entitas sehingga dapat mendeteksi lokasi objek dan menyediakan layanan sesuai dengan lokasi objek yang dikenal (Sari et al., 2016). Posisi consumer akan dibaca oleh sistem sesuai dengan posisi spasial gadget yang ter-install aplikasinya. Order yang dibuat oleh pelanggan akan di-broadcast ke semua driver yang berada pada radius terdekat. Jika driver yang mendapatkan notifikasi menerima order tersebut, maka baik consumer dan driver akan mengetahui posisi masing-masing di aplikasi mobile yang bersangkutan.

\subsection{Aplikasi Gojek}

Aplikasi Gojek yang dapat diakses melalui smartphone berbasis Android (PlayStore) maupun iOS (AppStore) ini memiliki 6 (enam) kelompok layanan dan terdiri atas 23 total layanan (tabel 3).

\begin{tabular}{|c|c|c|}
\hline Group & & Service \\
\hline A & Transport \& Logistics & $\begin{array}{ll}\text { 1. } & \text { GoRide } \\
\text { 2. } & \text { GoCar } \\
\text { 3. } & \text { GoSend } \\
\text { 4. } & \text { GoBox }\end{array}$ \\
\hline B & Food \& FMCG & $\begin{array}{ll}\text { 5. } & \text { GoFood } \\
\text { 6. } & \text { GoFood Festival } \\
\text { 7. } & \text { GoMed } \\
\text { 8. } & \text { GoMart } \\
\end{array}$ \\
\hline $\mathrm{C}$ & Payments & $\begin{array}{ll}\text { 9. } & \text { GoPay } \\
\text { 10. } & \text { GoBills } \\
\text { 11. } & \text { GoPoints } \\
\text { 12. } & \text { PayLater } \\
\text { 13. } & \text { GoPulsa }\end{array}$ \\
\hline $\mathrm{D}$ & Daily Needs & $\begin{array}{ll}\text { 14. } & \text { GoLife } \\
\text { 15. } & \text { GoMassage } \\
\text { 16. } & \text { GoClean } \\
\text { 17. } & \text { GoAuto } \\
\text { 18. } & \text { GoGlam } \\
\text { 19. } & \text { GoFix } \\
\text { 20. } & \text { GoLaundry } \\
\end{array}$ \\
\hline $\mathrm{E}$ & News \& Entertainment & $\begin{array}{ll}\text { 21. } & \text { GoPlay } \\
\text { 22. } & \text { GoTix }\end{array}$ \\
\hline $\mathrm{F}$ & Business & 23. GoBiz \\
\hline
\end{tabular}

Kelompok layanan Gojek tersebut yaitu: 1) Tranportasi \& Logistik (Transport \& Logistics), 2) Layanan Makanan (Food \& FMCG), 3) Pembayaran (Payments), 4) Kebutuhan Harian (Daily Needs), 5) Berita \& Hiburan (News \& Entertainment), dan 6) Bisnis (Business).

Perjalanan Gojek dimulai pada tahun 2010 sebagai pusat panggilan "ride-hailing" motor di Indonesia. Aplikasi homegrown kemudian diluncurkan pada 2015 dengan hanya tiga layanan: 1) GoRide, 2) GoSend, dan 3) GoMart.

Sampai dengan November 2018, Gojek telah membuka sejumlah cabang di wilayah ASEAN, seperti Vietnam (Go-Viet), Singapore (Gojek), Thailand (Get) dan Philippines. Per Oktober 2019, Gojek telah di-download lebih dari 50 juta kali di Google playstore dengan pengguna lebih dari 2 (dua) juta, serta ratusan ribu mitra.

Gojek telah menggunakan tampilan logo baru, "solv" yang dilengkapi dengan tag line “\#ThereIsAlwaysAWay". Logo baru tersebut simbol transformasi Gojek dari layanan ride-hailing menjadi Super App terbesar dengan 3 (tiga) platforms: 1) Aplikasi Pelanggan (Consumer), 2) Aplikasi Pengemudi (Driver), dan 3) Aplikasi Pedagang (Merchant), dengan berbagai cara cerdas untuk menghilangkan kerepotan (Gojek, 2019).

\subsection{Penggunaan UEQ untuk Analisis Aplikasi}

Pengalaman sehari-hari pengguna dengan situs web modern dan perangkat interaktif modern, seperti tablet atau smartphone, juga sangat meningkatkan harapan mengenai user experience perangkat lunak professional (Schrepp et al., 2014).

Kuisioner adalah alat yang umum digunakan untuk user-driven assessment terhadap kualitas (quality) dan kegunaan (usability) perangkat lunak.

Bidang Human-Computer Interaction (HCI) telah menjadi semakin peduli dengan user experience (Swallow et al., 2005). Konsep user experience (Rauschenberger et al., 2013) menggabungkan aspek-aspek terkenal seperti efisiensi (efficiency) dan efektivitas (effectiveness) dengan kriteria tambahan seperti estetika, kesenangan (aesthetics), penggunaan (joy-of-use) atau daya tarik (attractiveness).

\subsection{Generasi Milenial dan Generasi $Z$}

Siapa pun yang lahir antara 1981 dan 1996 (usia 23 hingga 38 tahun 2019) dianggap sebagai seorang Milenial, dan siapa pun yang lahir sejak 1997 dan seterusnya adalah bagian dari generasi baru (Dimock, 2019). Generasi baru tersebut dikenal dengan istilah generasi z. Tabel 4 memberikan kisaran rentang usia dari tiap generasi.

Generasi milenial memiliki kebiasaan yang meningkat untuk mencari produk atau layanan lokal saat "out and about" (Murillo, 2017), menciptakan peluang baru, terutama bagi pedagang kecil, yang dapat memanfaatkan lokasi mereka menggunakan 
iklan penelusuran seluler untuk menjangkau konsumen terdekat yang secara geografis mencari produk atau layanan mereka.

Generasi Y atau kaum Milenial (Clark, 2017) tumbuh dewasa menggunakan komputer, ponsel, tablet, dan perangkat elektronik lainnya, generasi Y individu sangat cerdas secara teknologi dan sangat terhubung ke Internet. Sedangkan generasi $\mathrm{z}$ (Wiedmer, 2015), meskipun muda, tampaknya akan memobilisasi penyebab dan lebih sadar secara sosial dan lingkungan daripada generasi sebelumnya.

Tabel 4. Generasi dan Usia pada tahun 2019

\begin{tabular}{lcc}
\multicolumn{1}{c}{ Generasi } & Periode Kelahiran & $\begin{array}{c}\text { Perkiraan Usia } \\
\text { pada Tahun 2019 }\end{array}$ \\
\hline $\begin{array}{l}\text { Silent } \\
\text { (veterans, } \\
\text { traditionalist) }\end{array}$ & $1928-1945$ & $74-91$ \\
\hline Baby Boomers & $1946-1964$ & $55-73$ \\
\hline $\begin{array}{l}\text { Generation } X \\
\text { (gen Xers, } \\
\text { busters) }\end{array}$ & $1965-1980$ & $39-54$ \\
\hline $\begin{array}{l}\text { Generation } X \\
\text { (gen Yers, } \\
\text { millennials, } \\
\text { nexters) }\end{array}$ & $1981-1996$ & $23-38$ \\
\hline \begin{tabular}{l} 
Generation $Z$ \\
\hline
\end{tabular} & $1997-2012$ & $7-22 *$ \\
\hline
\end{tabular}

\subsection{Penelitian Terkait}

Sejumlah penelitian terkait dengan "user experience" dan "online transportation" menjadi rujukan untuk penelitian ini.

meCUE questionnaire (Minge et al., 2017) terdiri atas 4 (empat) modul terpisah yang merujuk ke: 1) instrumental and non-instrumental product perceptions, 2) user emotions, 3) consequences of usage, dan 4) an overall judgment of attractiveness. Selanjutnya, penelitian terkait analisis service quality (Silalahi et al., 2017) untuk layanan transportasi online yang melibatkan 3 (tiga) dimensi: 1) service quality, 2) information quality, dan 3) system quality. Kemudian penelitian terkait faktor-faktor yang memengaruhi behavioral intention in Online Transportation Service diturunkan dari teori: 1) Technology Acceptance Model (TAM), 2) Theory of Planned Behavior (TPB), dan 3) Diffusion of Innovation (DOI).

Dari sejumlah penelitian yang telah dilakukan, belum ada yang menggunakan UEQ pada layanan transportasi online berbasis m-Commerce. Peneliti melakukan penelitian untuk mengetahui bagaimana user experience (genegrasi milenial dan z) menggunakan layanan online transportation berbasis m-Commerce, Gojek.

\section{Metode}

Penelitian ini merupakan penelitian kuantitatif dengan melakukan observasi, penyebaran kuesioner, dan telaah pustaka. Metode-metode tersebut disinergikan untuk mendeskripsikan semua fakta yang terkait dengan pengalaman mahasiswa generasi milenial dan $\mathrm{z}$ dalam menggunakan layanan transportasi online.

Bagian ini dibagi menjadi 4 (empat) sub-bagian. Sub-bagian pertama menjelaskan kuesioner pengalaman pengguna yang digunakan dalam penelitian ini. Sub-bagian kedua menginformasikan bagaimana kuesioner didistribusikan. Sub-bagian ketiga menjelaskan tentang responden yang terlibat dalam penelitian ini serta subjek yang saat ini mereka ikuti ketika mengisi kuesioner. Sub-bagian terakhir membahas objek aplikasi smartphone, Gojek.

\subsection{User Experience Questionnaire (UEQ)}

Penelitian ini menggunakan online user experience questionnaire (UEQ) (Schrepp et al., 2018). UEQ terdiri atas 6 (enam) variabel, yaitu: 1) Daya Tarik (Attractiveness), 2) Kejelasan (Perspicuity), 3) Efisiensi (Efficiency), 4) Ketepatan (Dependability), 5) Stimulasi (Stimulation), dan 6) Kebaruan (Novelty). Total ada 26 pertanyaan. Kuesioner ini adalah ukuran yang mudah diterapkan, andal, dan valid untuk pengalaman pengguna (Laugwitz et al., 2008). Contoh pertanyaan untuk variabel "Attractiveness" terlihat pada gambar 1 .

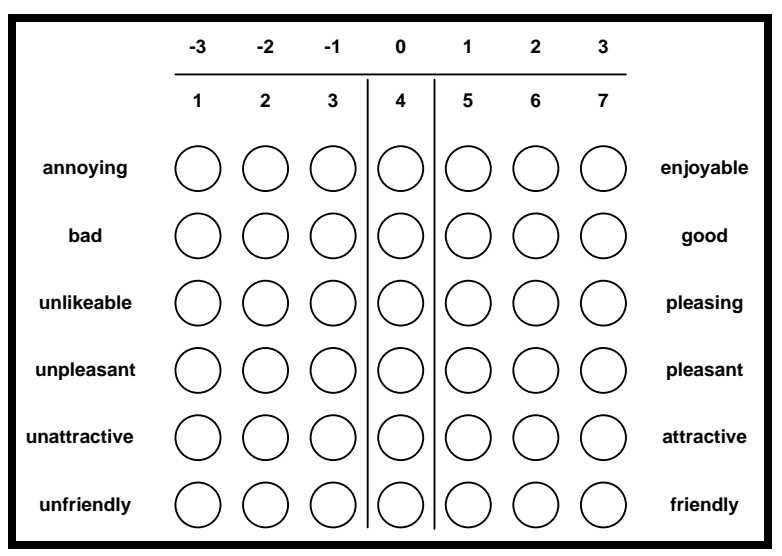

Gambar 1. Contoh item pertanyaan "Attractiveness".

Variabel "Attractiveness" dilihat dari 6 (enam) indicator: 1) annoying/enjoyable, 2) bad/good, 3) unlikeable/pleasing, 4) unpleasant/pleasant, 5) unattractive/attractive, dan 6) unfriendly/friendly.

Variabel "Perspicuity" dilihat dari 4 (empat) indikator: 1) not understandable/understandable, 2) difficult to learn/easy to learn, 3) complicated/easy, dan 4) confusing/clear.

Variabel "Efficiency" dilihat dari 4 (empat) indikator: 1) slow/fast, 2) inefficient/efficient, 3) impractical/practical, dan 4) cluttered/organized.

Variabel "Dependability" dilihat dari 4 (empat) indikator: 1) unpredictable/predictable, 2) obstructive/supportive, 3) not secure/secure, dan 4) does not meet expectations/meet expectations.

Variabel "Stimulation" dilihat dari 4 (empat) indikator: 1) inferior/valuable, 2) boring/exiting, 3) not interesting/interesting, dan 4) demotivating /motivating. 
Variabel "Novelty" dilihat dari 4 (empat) indikator: 1) duil/creative, 2) conventional/inventive, 3) usual/leading edge, dan 4) conservative/innovative.

Kuesioner terdiri dari pasangan atribut yang bertentangan dalam makna yang dapat mewakili produk. Lingkaran yang berada di antara atribut mewakili gradasi antara atribut yang berbeda. Responden dapat menyatakan persetujuan dengan atribut yang ada dengan memilih lingkaran yang lebih dekat dengan kesan. Item diskalakan dari -3 hingga +3 . Jadi, -3 mewakili jawaban paling negatif, 0 jawaban netral, dan +3 jawaban paling positif.

Setiap item pertanyaan terdiri atas 7 (tujuh) gradasi pilihan. Contoh pertanyaan untuk variabel "Attractiveness" dapat dilihat pada gambar 1.

\subsection{Distribusi Kuesioner}

Kuesioner dibuat dengan menggunakan aplikasi Google Forms. Aplikasi ini memiliki fitur yang sangat kaya dan fleksibel yang disusun sesuai dengan kebutuhan kuesioner serta untuk memfasilitasi interaksi dengan responden. Proses pengaturannya tidak terlalu lama. Setelah semua objek dipasang di google form, maka ia dapat dengan mudah dibagikan melalui Email, URL, atau Embed HTML (Abdillah, 2016). Gambar 2 memperlihatkan contoh beberapa pertanyaan yang ada pada tampilan kuesioner yang dibuat dengan menggunakan google form.

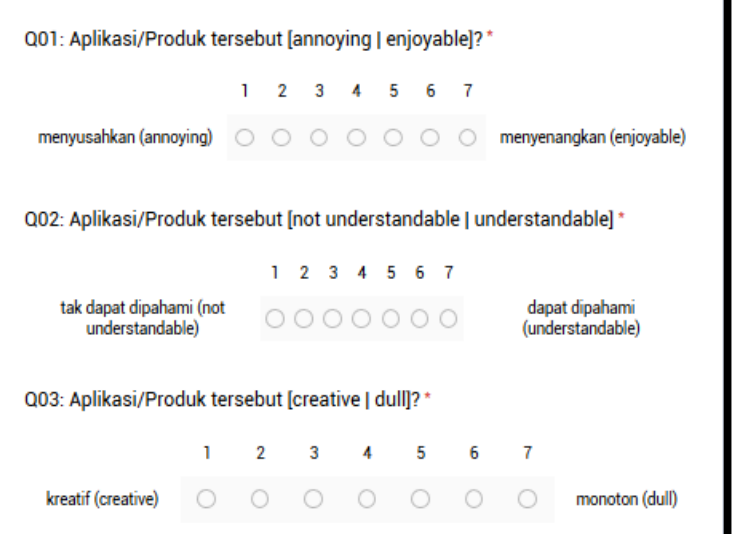

Gambar 2. Contoh item pertanyaan di google form.

Pada penelitian ini, URL user experience questionnaire didistribusikan melalui grup di media sosial yang banyak digunakan oleh generasi milenial dan z yaitu Facebook atau WhatsApp. Setelah umpan balik yang diberikan oleh para responden, Google Form akan membuat catatan dinamis (Roseth et al., 2013) secara otomatis.

\subsection{Analisis Data}

User experience questionnaire memberikan kesan komprehensif tentang pengalaman pengguna, mulai dari aspek kegunaan klasik hingga aspek pengalaman pengguna (Santoso et al., 2016). Ini juga menyajikan alat analisis untuk secara akurat menafsirkan hasil dengan mudah.

Analisis data dilakukan secara otomatis melalui tool yang sudah disediakan oleh user experience questioinnaire. Tool tersebut dapat di-unduh pada laman www.ueq-online.org. dengan tool tersebut data yang dimasukkan akan dihitung mean, variance, serta dilengkapi dengan benchmark-nya.

\subsection{Responden and Subjek Mata Kuliah}

Sekitar 154 dari 189 mahasiswa terlibat sebagai responden dalam penelitian ini. Responden yang terlibat merupakan mahasiswa aktif yang menjawab pertanyaan-pertanyaan yang ada pada user experience questionnaire. Mereka merupakan mahasiswa tingkat 2 (dua) yang mengambil mata kuliah "Human-Computer Interaction", HCI (Abdillah, 2018; Dix et al., 2004; MacKenzie, 2013; Preece et al., 2015).

HCI adalah salah satu mata kuliah inti yang diajarkan sejak beberapa dekade lalu. Materi HCI yang diajarkan kepada mahasiswa program studi sistem informasi meliputi: 1) HCI Introduction, 2) Human Aspects, 3) Interaction Elements, 4) Computer Aspects, 5) Interaction Paradigms, 6) Interaction Design, Navigation and Dialogue, 7) Prototype, 8) Evaluation (Usability), 9) Hypertext, multimedia and the world-wide web, dan 10) Ubiquitous computing and augmented realities. Salah satu materi yang diajarkan pada mata kuliah HCI adalah "User Experience".

\section{Hasil dan Pembahasan}

Berikut akan diuraikan sejumlah hasil observasi terhadap aplikasi Gojek dan analisis dari kuesioner yang telah disebarkan dan diolah.

\subsection{Tampilan Aplikasi Gojek (Android)}

Gojek memberikan fasilitas kepada para penggunanya untuk memilih sejumlah layanan yang sering digunakan atau diakses menjadi layanan favorit. Layanan-layanan yang telah dimasukkan ke layanan favorit akan muncul di layar utama (gambar 3).

Pada layar utama bagian atas Aplikasi Gojek dilengkapi dengan area untuk melakukan pencarian (search) dan icon promo. Gojek secara insentif memberikan sejumlah promo utnuk menarik minat consumer-nya.

Pada area kedua, tertera informasi saldo GoPay, kemudian 4 (empat) menu, yaitu: 1) Bayar, 2) Promo, 3) Isi Saldo, dan 4) Lainnya.

Pada bagian tengah layar Aplikasi Gojek berisi 7 (tujuh) layanan-layanan utama dari Aplikasi Gojek yang dijadikan layanan favorit oleh consumer, sehingga pada bagian ini bisa berbeda-beda antar consumer. Pada bagian ini ada menu ke-delapan yaitu Menu "Lainnya". Jika consumer menekan 
Menu "Lainnya" ini, maka semua layanan yang tidak termasuk ke layanan favorit akan muncul.

Dibawah bagian utama ada bagian "Konten buat kamu". Bagian ini berisi informasi-informasi yang secara berkala di-update oleh Aplikasi Gojek. Isi bagian ini disesuaikan dengan history transaksi yang sering dilakukan oleh consumer. Jika consumer sering melakukan pesanan order food, maka bagian ini akan menampilkan sejumlah promo terkait food.

Pada bagian bawah atau bagian footer, Aplikasi Gojek dilengkapi dengan 5 (lima) menu, yaitu: 1) Beranda, 2) Pesanan, 3) Chat, 4) Inbox, dan 5) Akun. Bagian footer ini akan terus nampak sewaktu consumer sedang melakukan transaksi-transaksi untuk suatu layanan.

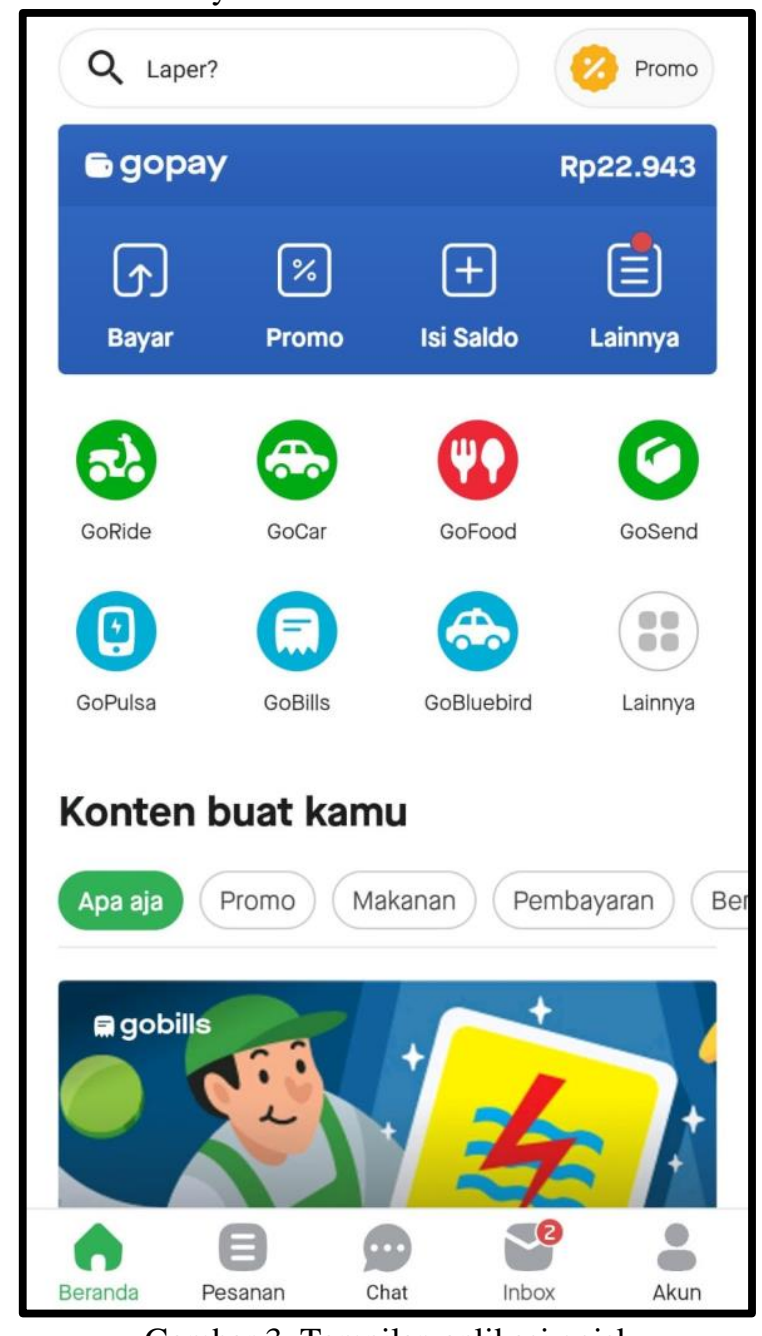

Gambar 3. Tampilan aplikasi gojek

\subsection{Hasil Analisis UEQ}

Setelah dilakukan perhitungan, hasil analisis menunjukkan bahwa semua kategori item pertanyaan memiliki hasil positif. Nilai antara $-0,8$ dan 0,8 mewakili evaluasi yang kurang lebih netral dari skala yang sesuai, nilai> 0,8 mewakili evaluasi positif dan nilai <-0,8 mewakili evaluasi negatif. Kisaran skala adalah antara -3 (sangat buruk) dan +3 (sangat baik).
Skor tertinggi diraih oleh kategori "Perspicuity" sedangkan skor terendah oleh kategori "Novelty" (lihat pada tabel 5).

Tabel 5. UEQ Scales (Mean and Variance)

\begin{tabular}{clrr}
\hline No & Variabel & Mean & Variance \\
\hline 1 & Attractiveness & 1,448 & 1,20 \\
2 & Perspicuity & 1,560 & 1,39 \\
3 & Efficiency & 1,472 & 1,28 \\
4 & Dependability & 1,244 & 1,20 \\
5 & Stimulation & 1,419 & 1,49 \\
6 & Novelty & 0,848 & 0,95 \\
\hline
\end{tabular}

Kategori "Attractiveness" memiliki skor 1,448, yang berada di area skor evaluasi positif (yang berkisar dari 0,8 hingga skor maksimum 3). Ini berarti bahwa para responden menyukai tampilan dari aplikasi Gojek.

Kategori "Perspicuity" mendapatkan skor 1,560, sekali lagi, menerima nilai evaluasi positif. Kategori "Perspicuity" mendapatkan skor tertinggi dibandingkan dengan kategori yang lain. Ini bermakna bahwa responden menemukan aplikasi Gojek mudah untuk dikenali.

Kategori "Efficiency" mendapatkan skor 1.472, yang membuat kategori efisiensi dari aplikasi Gojek menerima evaluasi positif. Ini berarti bahwa responden dapat menyelesaikan tugas mereka dengan mudah dan tidak perlu usaha yang tidak perlu.

Kategori "Dependability" menerima skor sebesar 1,244 , yang terletak pada area evaluasi positif. Ini berarti bahwa tombol yang ada pada aplikasi Gojek mengarahkan ke titik atau tempat yang tepat, dan aplikasi Gojek tidak mengarahkan ke titik atau tempat lain, membuat pengguna merasa mengendalikan interaksi.

Kategori "Stimulation" menerima skor sebesar 1.419, yang berada pada area evaluasi positif. Ini berarti bahwa pengguna merasa termotivasi untuk menggunakan aplikasi Gojek.

Kategori "Novelty" mendapatkan skor sebesar 0,95 , yang berada pada area positif. Skor ini sedikit di atas zona evaluasi netral yang berada pada rentang -0.8 sampai dengan 0.8. Kategori "Novelty" menerima hasil yang paling rendah dari semua kategori lain yang berarti bahwa pandangan aplikasi Gojek masih perlu meningkatkan kreativitasnya.

\subsection{Data Benchmarking}

Untuk mendapatkan gambaran yang lebih baik tentang kualitas suatu produk maka perlu untuk membandingkan pengalaman pengguna yang diukur dari produk dengan hasil dari produk mapan lainnya. UEQ menawarkan tolok ukur (Schrepp, 2015) yang berisi data dari 163 evaluasi produk dengan UEQ (dengan total 4818 peserta di semua evaluasi).

Benchmark mengklasifikasikan produk ke dalam 5 (lima) kategori (per skala): 1) Luar biasa (Excellent): Di kisaran 10\% hasil terbaik, 2) Bagus (Good): 10\% hasil dalam set data benchmark lebih baik dan $75 \%$ hasilnya lebih buruk, 3) Cukup baik 
(Above Average): $25 \%$ dari hasil dalam benchmark lebih baik daripada hasil untuk produk yang dievaluasi, 50\% dari hasil lebih buruk, 4) Kurang baik (Below Average): $50 \%$ hasil dalam tolok ukur lebih baik daripada hasil untuk produk yang dievaluasi, 25\% dari hasil lebih buruk, dan 5) Buruk $(\mathrm{Bad})$ : Di kisaran hasil terburuk $25 \%$.

Berdasarkan hasil penelitian, Gojek memiliki hasil benchmark seperti yang tertera pada tabel 6 dan nampak pada gambar 4.

Tabel 6. Benchmark gojek

\begin{tabular}{|c|c|c|c|c|}
\hline No & Category & Mean & $\begin{array}{l}\text { Comparison } \\
\text { to } \\
\text { benchmark }\end{array}$ & Interpretation \\
\hline 1 & Attractiveness & 1,45 & $\begin{array}{l}\text { Above } \\
\text { average }\end{array}$ & $\begin{array}{l}25 \% \text { of results } \\
\text { better, } 50 \% \text { of } \\
\text { results worse }\end{array}$ \\
\hline 2 & Perspicuity & 1,56 & Good & $\begin{array}{l}25 \% \text { of results } \\
\text { better, } 50 \% \text { of } \\
\text { results worse }\end{array}$ \\
\hline 3 & Efficiency & 1,47 & Good & $\begin{array}{l}25 \% \text { of results } \\
\text { better, } 50 \% \text { of } \\
\text { results worse }\end{array}$ \\
\hline 4 & Dependability & 1,24 & $\begin{array}{l}\text { Above } \\
\text { Average }\end{array}$ & $\begin{array}{l}25 \% \text { of results } \\
\text { better, } 50 \% \text { of } \\
\text { results worse }\end{array}$ \\
\hline 5 & Stimulation & 1,42 & Good & $\begin{array}{l}10 \% \text { of results } \\
\text { better, } 75 \% \text { of } \\
\text { results worse }\end{array}$ \\
\hline 6 & Novelty & 0,85 & $\begin{array}{l}\text { Above } \\
\text { Average }\end{array}$ & $\begin{array}{l}25 \% \text { of results } \\
\text { better, } 50 \% \text { of } \\
\text { results worse }\end{array}$ \\
\hline
\end{tabular}

Aplikasi Gojek memiliki 3 (tiga) kategori yang termasuk ke skala "Good", yaitu: 1) Kejelasan (Perspicuity), 2) Efisiensi (Efficiency), dan 3) Stimulasi (Stimulation).

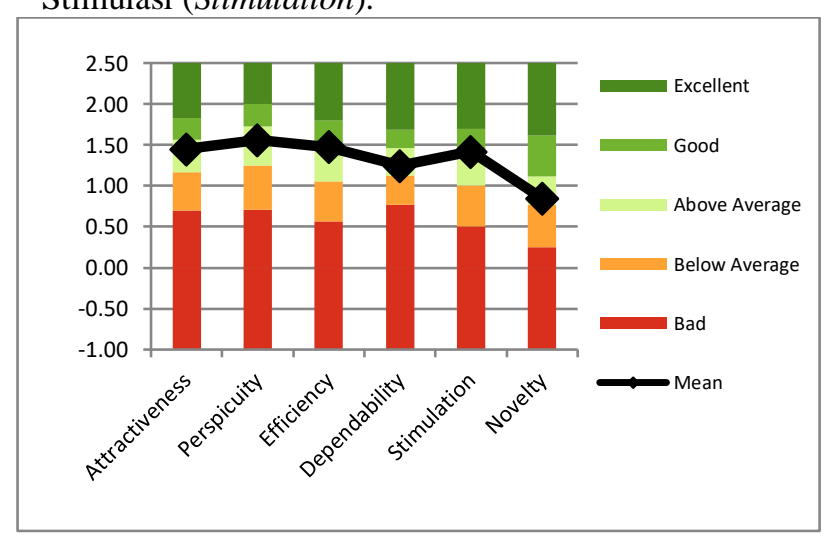

Gambar 4. Benchmark aplikasi gojek

Selanjutnya, aplikasi Gojek memiliki 3 (tiga) kategori yang masuk ke skala "Above Average", yaitu: 1) Daya Tarik (Attractiveness), 2) Ketepatan (Dependability), dan 3) Kebaruan (Novelty).

\section{Kesimpulan}

Berdasarkan hasil penelitian dapat ditarik beberapa simpulan: 1) Semua kategori penilaian user experience untuk aplikasi Gojek menunjukkan bahwa aplikasi Gojek berada pada area evaluasi positif. Hal ini mengindikasikan bahwa aplikasi Gojek memberikan pengalaman yang positif bagi para penggunanya. 2) Benchmark aplikasi Gojek berada pada skala "Good" dan "Above Average". Hal ini menunjukkan bahwa aplikasi Gojek merupakan aplikasi yang secara global memiliki kualitas yang relatif seimbang dengan aplikasi-aplikasi lainnya.

Secara keseluruhan, use experience questionnaire mampu memberikan analisis pengalaman pengguna generasi milenial dan $\mathrm{z}$ dalam menggunakan layanan transportasi online nomor 1 (satu) di Indonesia, Gojek.

Untuk tahap selanjutnya, peneliti tertarik untuk membandingkan user experience pengguna Gojek dengan pesaingnya, Grab.

\section{Daftar Pustaka}

Abdillah, L.A., 2016. Ujian online mahasiswa ilmu komputer berbasis Smartphone. Seminar Nasional Riset Ilmu Komputer Ke-2 (SNRIK2016), Makassar.

Abdillah, L.A., Napitupulu, D., Simarmata, J., Rahim, R., Abdullah, D. \& Pranolo, A., 2017. The role of big data and cloud computing for technology based business. The First International Conference on Education and Technology (ICEduTech2017), Novotel Hotel, Balikpapan, Indonesia.

Abdillah, L.A., 2018. Human Computer Interaction Computer Science \& Information Systems. Palembang: Universitas Bina Darma.

Clark, K.R., 2017. Managing multiple generations in the workplace. Radiologic Technology, 88(4), 379-396.

Dimitrijević, D., Nedić, N., \& Dimitrieski, V., 2013. Real-time carpooling and ride-sharing: position paper on design concepts, distribution and cloud computing strategies. Paper presented at the Federated Conference on Computer Science and Information Systems (FedCSIS2013), Kraków, Poland.

Dix, A., Finlay, J., Abowd, G.D., \& Beale, R., 2004. Human-Computer Interaction. Harlow, Essex, England: Pearson Education Limited.

Junita, I., 2019. Transformational leadership in digital era: analysis of nadiem makarim (founder of go-jek indonesia) leadership figure. Integrated Journal of Business and Economics, 3(1), 80-92.

Kemp, S., 2019. Digital 2019: Global Internet Use Accelerates. Diakses pada tanggal 1 September, 2019, dari https://wearesocial.com/blog/ 2019/01/digital-2019-global-internet-useaccelerates

Laugwitz, B., Held, T., \& Schrepp, M., 2008. Construction and evaluation of a user experience questionnaire. Symposium of the Austrian HCI and Usability Engineering Group. 
MacKenzie, I.S., 2013. Human-computer interaction: An empirical research perspective. Waltham, MA, USA: Newnes.

Minge, M., Thüring, M., Wagner, I., \& Kuhr, C.V., 2017. The meCUE questionnaire: a modular tool for measuring user experience. In F. C. Soares M., Ahram T. (Ed.), Advances in Ergonomics Modeling, Usability \& Special Populations (Vol. 486, pp. 115-128).

Murillo, E., 2017. Attitudes toward mobile search ads: a study among Mexican millennials. Journal of Research in Interactive Marketing, 11(1), 91108.

Poushter, J., 2016. Smartphone ownership and internet usage continues to climb in emerging economies. Pew Research Center, 22, 1-44.

Preece, J., Rogers, Y. \& Sharp, H., 2015. Interaction design: beyond human-computer interaction (4th ed.): John Wiley \& Sons.

Puspitasari, L., \& Ishii, K., 2016. Digital divides and mobile Internet in Indonesia: Impact of smartphones. Telematics and Informatics, 33(2), 472-483.

Rahardjo, D. \& Sugiarto, M., 2019. Valuation model using a mixed real options method: a review on Singapore and Indonesia digital startups. Paper presented at the 16th International Symposium on Management (INSYMA 2019), Manado, Indonesia.

Rauschenberger, M., Schrepp, M., Cota, M.P., Olschner, S. \& Thomaschewski, J., 2013. Efficient measurement of the user experience of interactive products. How to use the user experience questionnaire (UEQ). Example: Spanish language version. International Journal of Artificial Intelligence and Interactive Multimedia (IJAIIM), 2(1).

Roseth, C., Akcaoglu, M., \& Zellner, A., 2013. Blending synchronous face-to-face and computersupported cooperative learning in a hybrid doctoral seminar. TechTrends, 57(3), 54-59.

Santoso, H.B., Schrepp, M., Isal, R.Y.K., Utomo, A.Y. \& Priyogi, B., 2016. Measuring user experience of the student-centered e-learning environment. The Journal of Educators Online (JEO), 13(1).
Sari, I.O., Abdillah, L.A., \& Wardhani, K.R.N., 2016. Application Location Based Service (LBS) location search palembang nature-based android. Paper presented at the The 5th International Conference on Information Technology and Engineering Application (ICIBA2016), Palembang.

Schrepp, M., Hinderks, A. \& Thomaschewski, J., 2014. Applying the user experience questionnaire (UEQ) in different evaluation scenarios. Paper presented at the International Conference of Design, User Experience, and Usability.

Schrepp, M., 2015. User Experience Questionnaire Handbook.

Schrepp, M., Hinderks, A. \& Thomaschewski, J., 2018. User Experience Questionnaire. Mensch und Computer 2017-Tagungsband: Spielend einfach interagieren, 17, 355.

Septiani, R., Handayani, P.W., \& Azzahro, F., 2017. Factors that affecting behavioral intention in online transportation service: case study of GOJEK. Procedia Computer Science, 124, 504-512.

Silalahi, S.L.B., Handayani, P.W., \& Munajat, Q., 2017. Service quality analysis for online transportation services: Case study of GO-JEK. Procedia Computer Science, 124, 487-495.

Statista, 2019a. Number of internet users in selected countries in the Asia-Pacific region as of January 2019, by country (in millions). Diakses pada tanggal 1 September, 2019, dari https://www.statista.com/statistics/265153/numbe r-of-internet-users-in-the-asia-pacific-region/.

Statista, 2019b. Number of smartphone users in Indonesia from 2011 to 2022 (in millions)*. Diakses pada tanggal 1 September, 2019, dari https://www.statista.com/statistics/266729/smartp hone-users-in-indonesia/.

Swallow, D., Blythe, M., \& Wright, P., 2005. Grounding experience: relating theory and method to evaluate the user experience of smartphones. Paper presented at the Proceedings of the 2005 annual conference on European association of cognitive ergonomics.

Wiedmer, T., 2015. Generations do differ: Best practices in leading traditionalists, boomers, and generations X, Y, and Z. The Delta Kappa Gamma Bulletin: International Journal for Professional Educators, 82(1). 